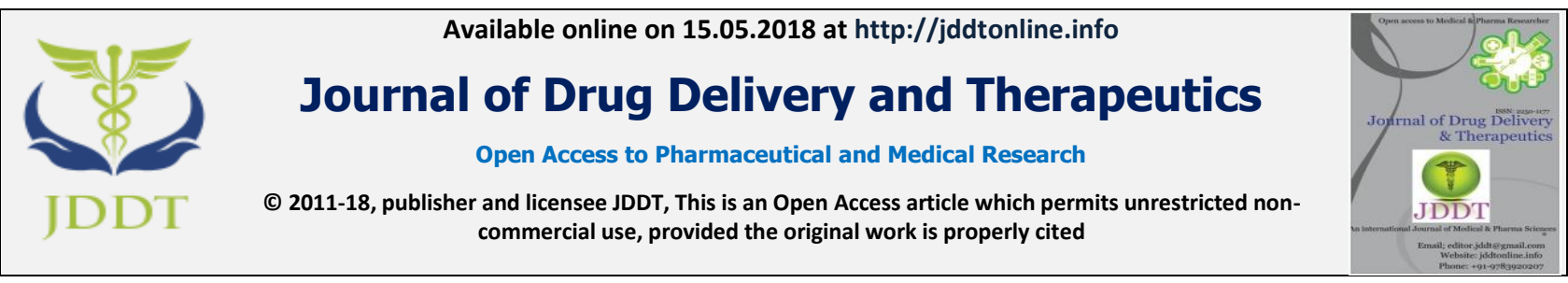

Open $\bigcirc$ Access

Research Article

\title{
CITRUS LIMON LEAVES FROM NORTH-EASTERN INDIA: A POTENTIAL SOURCE OF ANTHELMINTIC AGENT AGAINST EICINIA FOETIDA
}

\author{
Elija Khatiwora \\ Department of Chemistry, Y.M. College, Bharati Vidyapeeth Deemed University, Pune-38, India
}

\begin{abstract}
Citrus limon L Burmf or Assam limon belongs to family Rutaceae. Citrus food and derive product have beneficial impacts on human health. More than just a vitamin $\mathrm{C}$ rich fruits, lemon is a powerful medicinal plant with numerous benefits that have been enjoyed for over 3000 years. Helminthiasis or worm infection is a common infection in human, affecting a large population of the word. Considering this, anthelmintic activity of citrus limon L Burmf leaves was carried out in this experiment. Ethyl acetate, acetone, methanol extracts of citrus limon leaves have been evaluated for anthelmintic activity against Indian Earthworm species Eicinia foetida. The results reveal a dose dependent increase in activity of the extracts at 5,10 and $20 \mathrm{mg} / \mathrm{ml}$ concentrations. All the extracts exhibited better activity then standard compound Albendazole. Acetone extract exhibited highest activity among the extract.
\end{abstract}

Keyword: Anthelmintic activity; Eicinia foetida, Albendazole.

\section{INTRODUCTION}

Helminthiasis or worm infection is a common infection in human, affecting a large population of the world. Helminthiasis is one of the major causes of gastrointestinal disorder ${ }^{1}$. It also affects the productivity loss of small ruminant livestock and pets ${ }^{\mathbf{1}}$. Parasitic worm also affects livestock crops affecting food production with a resultant economic impact. The infections due to worm are a great threat to health and contribute to the prevalence malnutrition, anemia, pneumonia etc ${ }^{2}$. Despite this prevalence of parasitic infections, the research on anthelmintic drug is limited ${ }^{3}$. Anthelmintic are drugs that may act locally to expel worms from the gastrointestinal tract (GIT) or systematically to eradicate adult helminths or development forms that invade organs and tissues ${ }^{4}$. Most of the existing anthelmintic produces nausea, vomiting head ache and diarrhea. Chemotherapy is the only treatment and effective tool to cure and control helminths. Effective vaccines against helminths have not been developed so far ${ }^{4}$. Indiscriminate use of synthetic anthelmintic can lead to resistance of parasites 5 . Herbal drugs have been in use since ancient times for the treatment of parasitic diseases in human and could be of value of in preventing the development of resistance ${ }^{\mathbf{6}}$.

Citrus limon L Burmf belongs to family rutaceae is also known as Assam lemon and one of the most important crops of Assam and other parts of north eastern region. Fruit is widely used for culinary, beverages, industrial and medicinal uses. The fruits are sour, rich in vitamin C Which strengthens the immune system, acts as an antioxidant and protects cells from radical damage ${ }^{7}$. Infusion of the bark or peel of the fruits is given to relive colic. It is used as antiseptic, antibiotic and antiviral. Traditionally, citrus limon claims as anthelmintic but scientifically it is not reveled still ${ }^{\mathbf{8 , 9}}$. Thus, the present study was design to evaluate the in-vitro anthelmintic activity of different solvent extract of citrus limon. Anthelmintic activity Citrus limon fruit empty juice sacs were investigated ${ }^{\mathbf{1 0}}$. Comparative study of antioxidants 
changes including total flavonoid, total phenol and total antioxidant capacity of Citrus limon fruits grown at the north of Iran were examined ${ }^{\mathbf{1 1}}$. Antimicrobial activity of juice in ripens and unripe forms of C.limon were studied

Preliminary qualitative phytochemical screening of C.limon L Burmf leaves revealed the presence of phenolic compounds, terpenoids, flavonoids and steroids. These phytochemicals are responsible for biological activity of plant. Considering its various biological activities, anthelmintic activity of leaves extracts was carried out in this experiment. As per the available reports this is the first study of anthelmintic activity of ethyl acetate, acetone and methanol extracts of citrus limon L Burmf leaves collected from Biswanath district, Assam, India.

\section{MATERIAL AND METHOD}

The plant material was collected from Naduar area, Biswanath chariali district, Assam, India.

The plant was authenticated at Department of Life Sciences, Dibrugarh University, Assam, India.

Preparation of plant extract: Air shade dried and powdered leaves material of Citrus limon L Burmf (50 $\mathrm{mg}$ ) was treated separately with ethyl acetate, ethanol and methanol $(250 \mathrm{ml})$ by refluxing for 18 hours. Solvents were recovered under reduced pressure to obtain the crude extracts.

\section{Anthelmintic activity-}

\section{Chemicals-}

Albendazole, normal saline were parched from authorized pharmaceuticals. The solvents and other chemicals used during experimental protocol were of analytical grade.

\section{Animal-}

Indian earthworm species Eicinia foetida was collected from Mahatma Phule Agriculture University, Pune. Maharashtra, India. All earthworms were of approximately equal size ${ }^{\mathbf{9 - 1 0}}$.

The anthelmintic assay was carried out as per the method reported by Ajaycoba et al with minor modification ${ }^{13}$. The assay was performed on adult Indian Earth worm species Eicinia foetida due to its anatomical and physiological resemblance with the intestinal round worm parasite of human being. Albendazole with normal saline solution was used as standard $(5,10,20 \mathrm{mg} / \mathrm{ml})$ and normal saline was served as control. Extracts in same concentration in normal saline solution were used. The time taken for complete paralysis and death was recorded. External stimuli were applied as ascertain the paralysis time. The time taken by worm to become motionless was considered as paralysis time and lethal time was ascertained by death of motionless worm followed by fading of their body colour.

\section{Administration of extract-}

The suspension of different solvent extract of citrus limon L Burmf leaves, different concentration (5$20 \mathrm{mg} / \mathrm{ml}$ ) were prepared using 5-20 mg extract dissolved in $5 \mathrm{ml}$ and final volume is made to $10 \mathrm{ml}$ for respective concentration $(5 \mathrm{mg} / \mathrm{ml}, 10 \mathrm{mg} / \mathrm{ml}, 20 \mathrm{mg} / \mathrm{ml})$ of citrus limon leaves. Five groups of approximately equal size worms consisting of five earthworms individually in each group were released into $10 \mathrm{ml}$ of desired concentration of drug and extracts.

\section{Administration of Albendazole-}

Albendazole $(5,10,20 \mathrm{mg} / \mathrm{ml})$ was used prepared by using $50 \mathrm{mg}, 100 \mathrm{mg}$, and $200 \mathrm{mg}$ powder in $10 \mathrm{ml}$ saline as a suspending agent.

\section{Statistical Analysis-}

All the results were expressed as mean \pm S.D. of five animals in each group.

\section{Anthelmintic effect of citrus limon leaves in Indian earthworm (Eicinia foetida)}

For evaluation of anthelmintic activity of citrus limon leaves, group I, II and III received normal saline and standard Albendazole while group IV, V and VI received different concentration of acetone extract, VII, VIII, and IX received different concentration of methanol extract and X, XI and XII received ethyl acetate extract of citrus limon leaves respectively.

\section{RESULT AND DISCUSSION}

Table 1: Anthelmintic potency of citrus limon leaves

\begin{tabular}{|l|l|l|l|l|}
\hline Treatment & Group & Concentration $\mathbf{( M g} / \mathbf{m l})$ & Time of paralysis $(\mathbf{m i n})$ & Time of death $(\mathbf{m i n})$ \\
\hline \multirow{5}{*}{ Albendazole } & I & 5 & $202 \pm 2.34$ & $178 \pm 1.78$ \\
\cline { 2 - 5 } & II & 10 & $247 \pm 4.06$ & $168 \pm 1.58$ \\
\cline { 2 - 5 } & III & 20 & $200 \pm 1.64$ & $155 \pm 1.81$ \\
\hline \multirow{5}{*}{ Acetone } & IV & 5 & $90 \pm 1.14$ & $66 \pm 1.81$ \\
\cline { 2 - 5 } & V & 10 & $88 \pm 1.41$ & $60 \pm 1.48$ \\
\cline { 2 - 5 } & VI & 20 & $85 \pm 2.60$ & $58 \pm 2.12$ \\
\hline \multirow{5}{*}{ Methanol } & VII & 5 & $200 \pm 1.81$ & $100 \pm 1.51$ \\
\cline { 2 - 5 } & VII & 10 & $178 \pm 1.30$ & $124 \pm 1.67$ \\
\cline { 2 - 5 } & IX & 20 & $160 \pm 1.51$ & $79 \pm 1.64$ \\
\hline \multirow{5}{*}{ Ethyl acetate } & X & 5 & $194 \pm 1.14$ & $164 \pm 1.94$ \\
\cline { 2 - 5 } & XI & 10 & $181 \pm 2.16$ & $165 \pm 1.30$ \\
\cline { 2 - 5 } & XII & 20 & $174 \pm 1.92$ & $145 \pm 1.92$ \\
\hline
\end{tabular}


All values represent Mean \pm S.D; $n=5$ in each group. All values are significantly different from reference standard (Albendazole). This activity was concentration dependent. The potency was found to be inversely proportional to the time taken for paralysis and time of death of the worms.

From the above result, it is clear that acetone extract of citrus limon leaves has significant anthelmintic activity in dose dependent manner when compared with standard anthelmintic drug. All the three extracts exhibited better activity compared to standard drug albendazole. It can be concluded that the active constituents responsible for anthelmintic activity present in leaves extract of citrus limon. Further study is needed to isolate and revealed the active compound in the crude extract of citrus limon and to established mechanism of action are required.

\section{CONCLUSION}

Citrus limon L Burmf or Assam limon leaves extracts are found to do superior anthelmintic agent then the standard compound albendazole. So, it can be concluded that $C$ limon leaves extracts have great potential as anthelmintic agent. It can be evaluated as a potential source of natural bioactive chemicals and correlate relationship of these secondary metabolites to possible biological activities.

\section{ACKNOWLEDGEMENT}

The author is thankful to the principal, Y.M. College, Bharati Vidyapeeth Deemed University, Pune-411038, India for providing the necessary support to carry out this work.

\section{REFERENCES}

1. Quattra M, Sissouma D, Kone MW, Menan HE, Toure SA, Quattara L, Tropical Journal of Pharmaceutical Research 2011; 10(6):767-776.

2. Bundy DA, Trans Royel Soc Trop Med Hyg 1994; 8:259261.

3. Aswar M, Aswar U, B. watkar, Int. J. Green pharma 2008; $170-173$

4. Goodman LS. Gilman A. The pharmacological basis of Therapeutics. $10^{\text {th }}$ Edn.Mcgraw Hill Medical Published Division, New York, 2001, 1121.

5. Singh D, Swarnkar CP, Khan FA. Anthelnintic resistance in gastrointestinal nematodes in livestock in India, J Vet Parasite, 2002, 16:115-130.

6. Chopra RN, Nayer SC, Chopra IC.Glossary of Indian medicinal plants, CSIR, NewDelhi, 1956, 160.

7. http://en. wikipedia.org/wiki/lemon

8. The citrus plant,. In: citrus. Ciba-Geigy Agrochemicals Tech. Monogr.4. Ciba-Geigy Ltd., Basle, Switzerland, 1975, p.6-13

9. Hesperides. A history of the culture and use of Citrus. Fruits, p.371. John Bale, Sons and Curnow, 1938, London, England.

10. Munne S, Parwate D, Ingle V, Nagpurkar V, Evaluation of the anthelmintic activity of citrus limon juice sacs, Int J. Pharma Professional's Research, 2011;2(2).

11. Mohammadian MA, Mobram ZI, Sajedi RH, Bioactive compounds and antioxidant capacities in the flavedo tissue of two citrus cultivars under low temperature, Braz J Plant Physiol, 2011; 23(3):203-208.

12. Sarmah N, Kumari S, Comparative study of antibacterial activity of ripen and unripen Indigenous Citrus union of Assam, India, Int J Advancements in Research \& Technology, 2013; 2(9):25-31.

13. Ajayebo EO, Onocha PA,Olarenwaju OT, Pharma. Biol, 2001; 39:217-220. 